\title{
Notes on the vocalizations of Black-naped Monarch (Hypothymis azurea)
}

Peter Boesman

In the following we briefly analyze and compare voice of the different races of Black-naped Monarch (Hypothymis azurea). We also try to quantify the extent of any vocal differences using the criteria proposed by Tobias et al. (2010), as a support for taxonomic review. We have made use of sound recordings available on-line from Xeno Canto (XC).

There are presently 25 subspecies recognized, our main interest is to determine whether the morphologically distinct 'puella group' shows significant vocal differences compared to 'other races'.

A random selection of songs from 'other races':

India

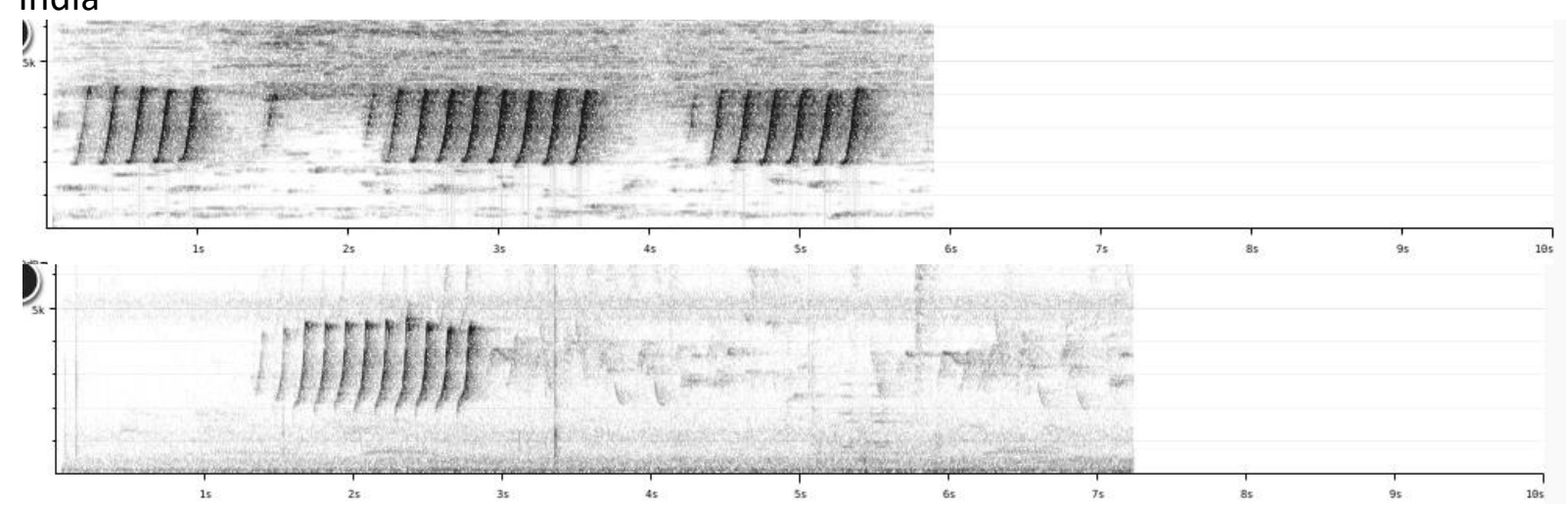

Malaysia

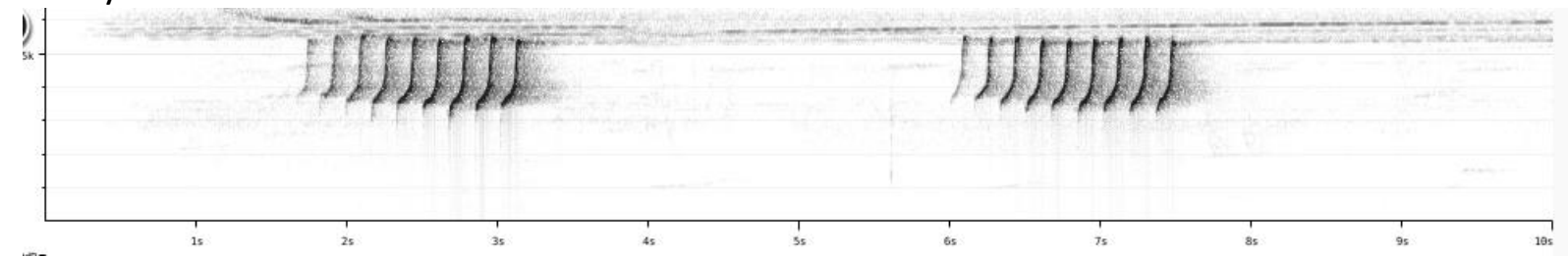

Cambodia

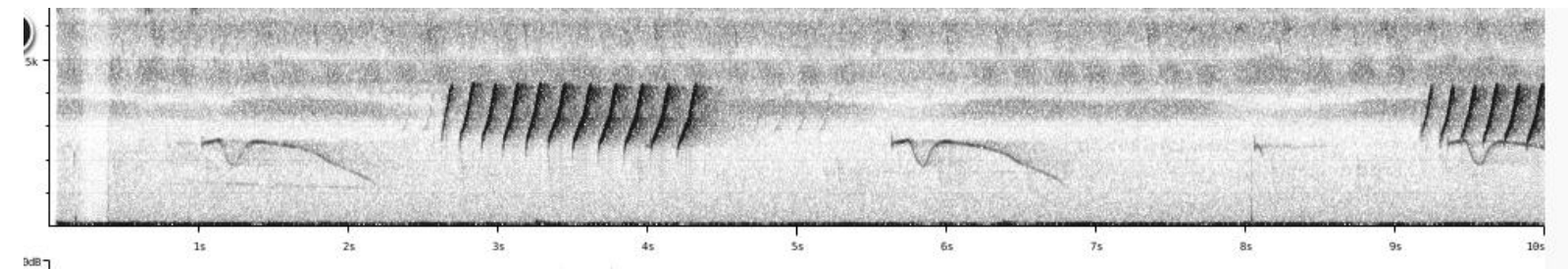

Vietnam

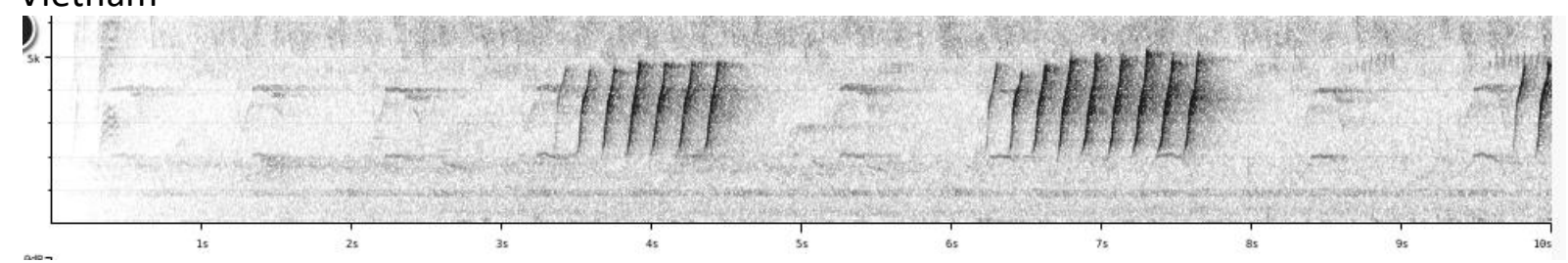




\section{HANDBOOK OF THE \\ BIRDSPF THE WORLD}

\section{ORNITHOLOGICAL NOTES}

China

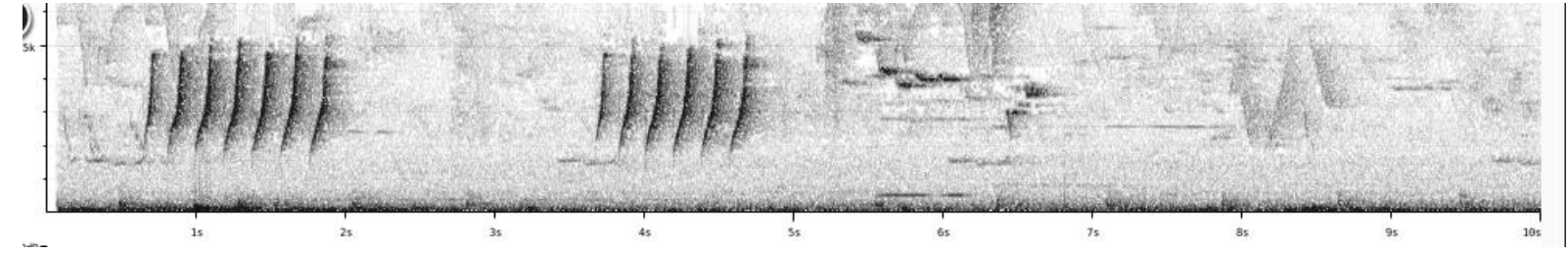

Taiwan

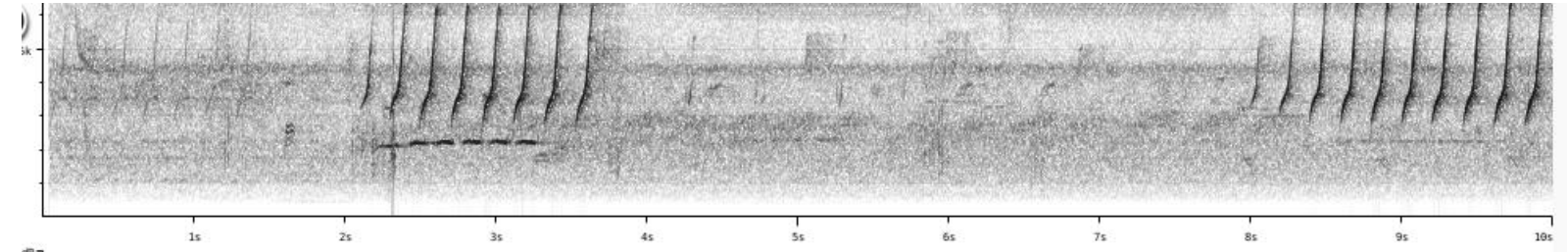

Alor, Indonesia

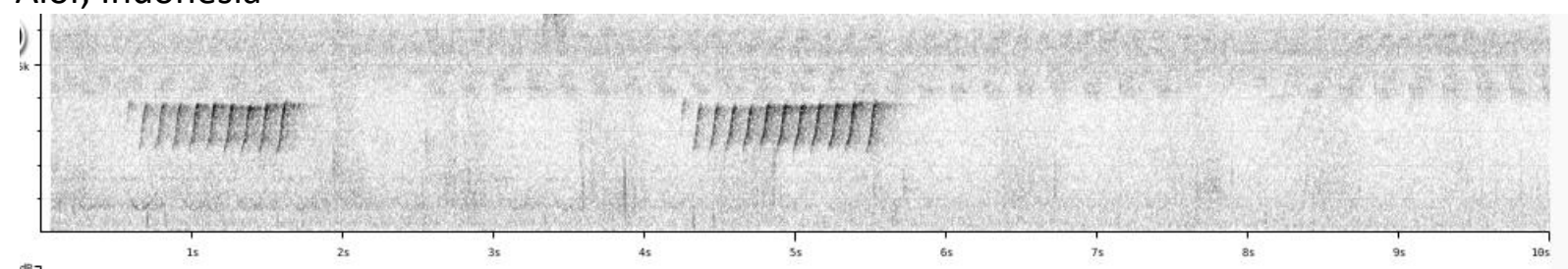

Philippines
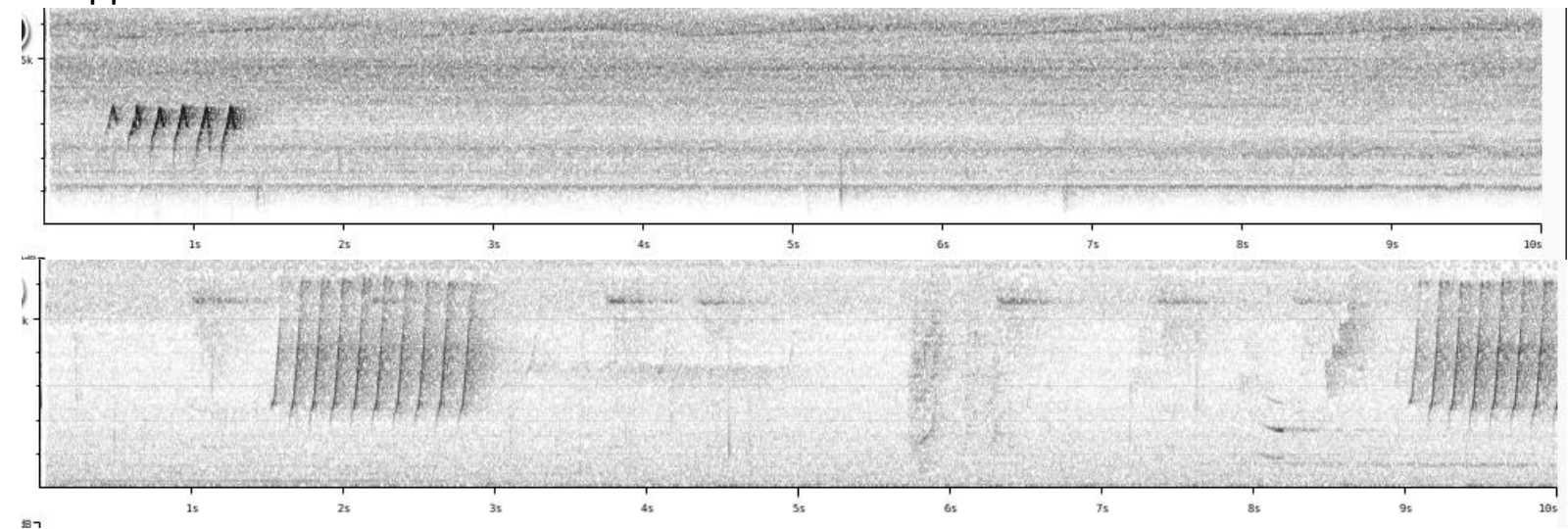

Song of the 'puella group':

\section{Race blasii}

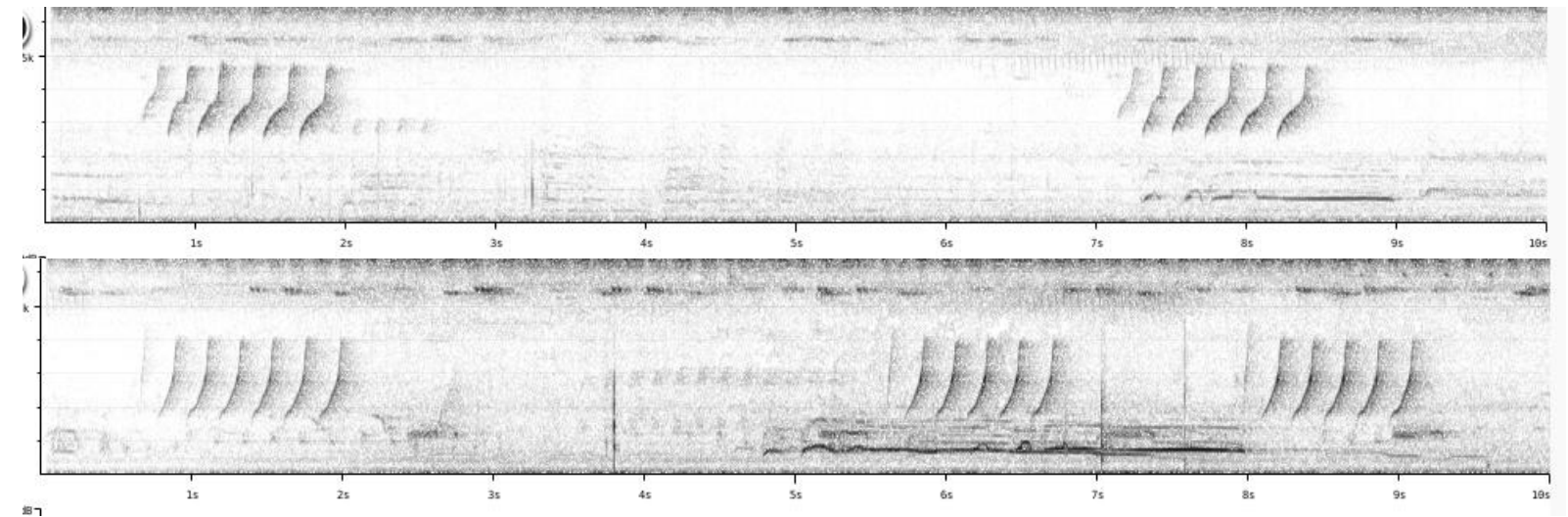




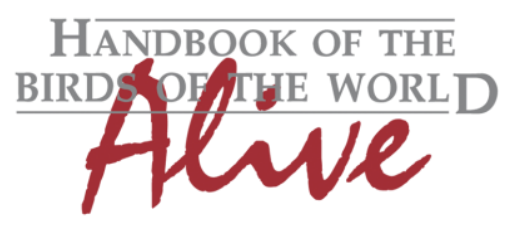

\section{ORNITHOLOGICAL NOTES}

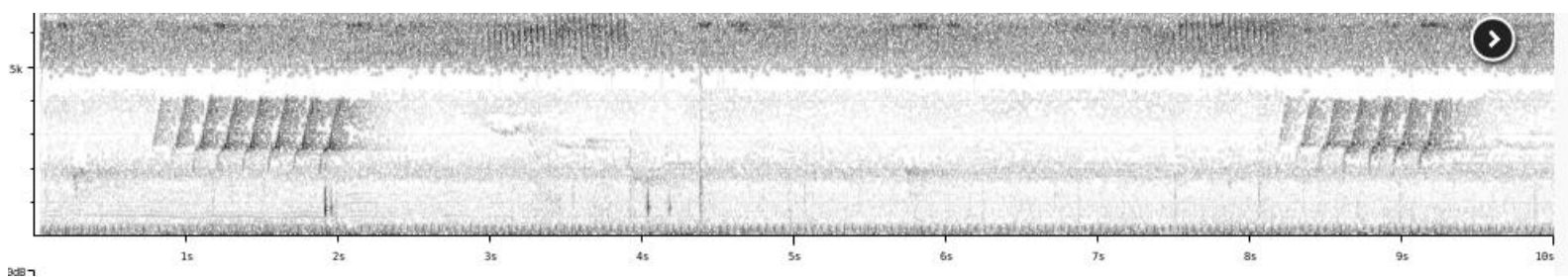

Race puella
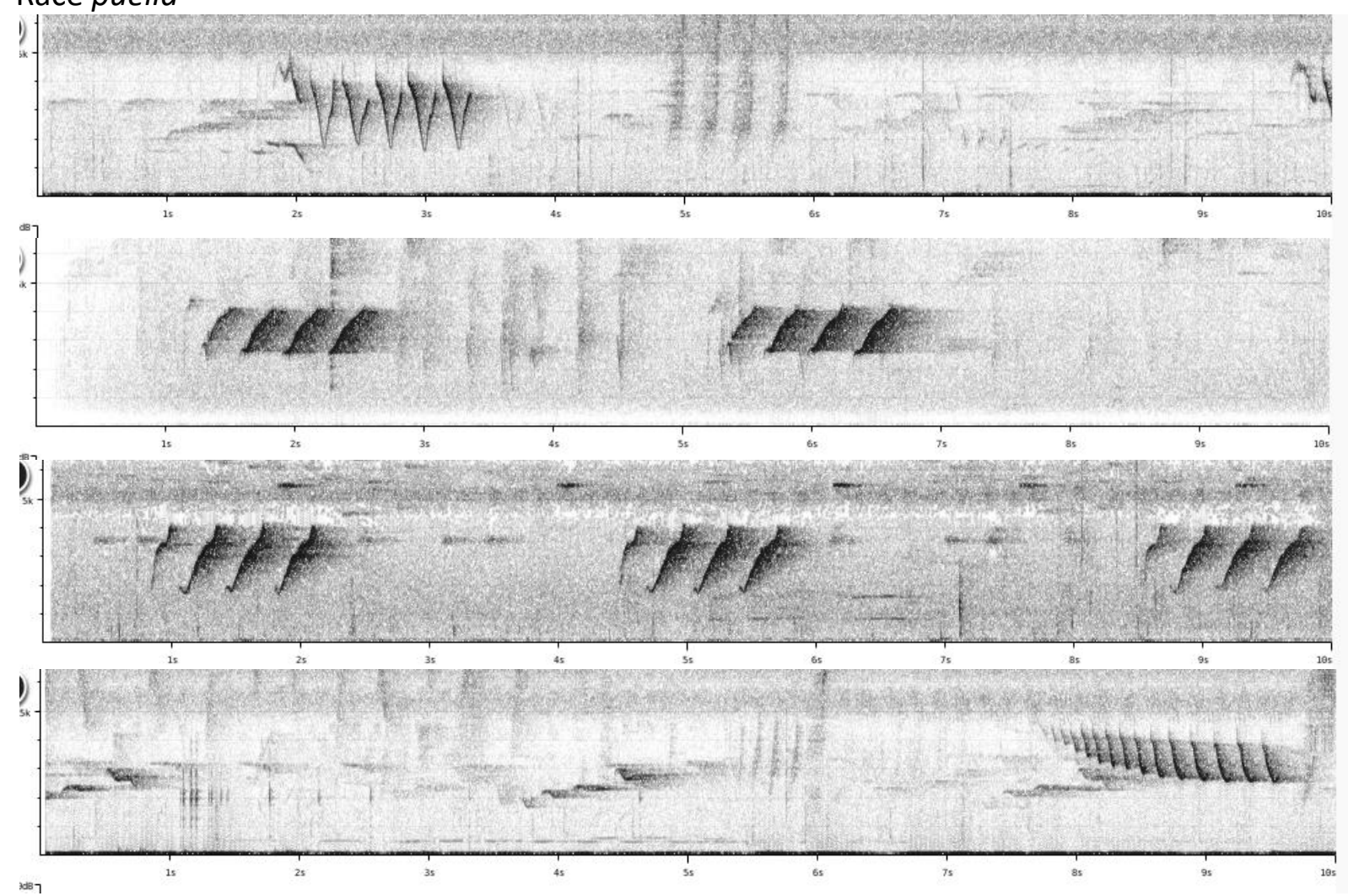

It is clear from the above examples that race puella has quite a different song, with more variation (versus the surprising uniformity over the vast range of the 'other races'), not pure repetitions of a single whistle but e.g. series descending in pitch, repeated double notes, series of fewer emphasized whistles at slow pace etc.. Also a few calls are unique for this taxon.

While it is difficult to pinpoint differences in basic sound parameters as it is not clear what can be considered homologous compared to the 'other races', race puella clearly has a distinctive vocabulary (which could be quantified as 3 song types vs a single song type).

It is quite surprising however that all examples of race blasii do NOT show this distinctiveness. It would seem that morphological and vocal evolution do not go hand in hand here. This will need further investigation. 
This note was finalized on 22nd January 2015, using sound recordings available on-line at that moment. We would like to thank in particular the sound recordists who placed their recordings of song for this species on XC: Pronoy Baidya, Peter Boesman, David Edwards, David Farrow, Chie-Jen Jerome Ko, Kuan-Chieh Hung, Pankaj Lad, Andrew Mascarenhas, Mike Nelson, Frank Lambert, Hans Matheve, Sander Pieterse, Vivek Puliyeri, Ramit Singal, Colin Trainor and Ding Li Yong.

\section{References}

Tobias, J.A., Seddon, N., Spottiswoode, C.N., Pilgrim, J.D., Fishpool, L.D.C. \& Collar, N.J. (2010). Quantitative criteria for species delimitation. Ibis 152(4): 724-746.

\section{Recommended citation}

Boesman, P. (2016). Notes on the vocalizations of Black-naped Monarch (Hypothymis azurea). HBW Alive Ornithological Note 197. In: Handbook of the Birds of the World Alive. Lynx Edicions, Barcelona. (retrieved from http://www.hbw.com/node/932142 on 30 August 2016). 